\section{Leopold Scholtz}

Retired Political

Commentator for News

Media, Military Historian and Research Fellow,

Research Focus Area

Social Transformation,

North-West University.

E-mail: leoscholtz@

yahoo.com

DOI: https://dx.doi. org/10.18820/24150509/

JCH42.v2.3

ISSN 0258-2422 (Print)

ISSN 2415-0509 (Online)

Journal for Contemporary

History

2017 42(2):48-73

(C) UV/UFS

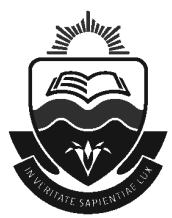

\section{THE BATTLE OF THE LOMBA, 3 OCTOBER 1987: A TACTICAL AND OPERATIONAL ANALYSIS}

\begin{abstract}
The Battle of the Lomba, which was fought on 3 October 1987, was the final contest between the South African Defence Force (SADF) and Forças Armadas Populares de Libertação de Angola (FAPLA) during the first phase of Operation Moduler. In this battle, 61 Mechanised Battalion Group (61 Mech; with a Ratel 90 squadron as the battering ram) attacked the vastly superior Angolan 47 Brigade and all but wiped it out. The basic question in this article is why and how this happened? The answer lies in the tactical and operational handling of both forces on a command level. On the one side, from a professional viewpoint, the SADF leadership of 20 SA Brigade and 61 Mech did almost everything correctly, and even lay the foundation of the victory before a single shot was fired. The Angolan commanders did almost everything wrong. The tactical and operational lessons learnt from the battle may provide material for officers' training, and these lessons are discussed as part of the conclusion.
\end{abstract}

Keywords: South African Defence Force (SADF); Forças Armadas Populares de Libertação de Angola (FAPLA); União Nacional Para a Independência Total de Angola (UNITA); Movimento Popular de Libertação de Angola (MPLA); Namibia; Angola; Operation Moduler; Operación Saludando á Octubre; Ratel; T-54; T-55, Deon Ferreira; Bok Smit; 61 Mechanised Battalion Group (61 Mech); 47 Brigade.

Sleutelwoorde: Suid-Afrikaanse Weermag (SAW); Forças Armadas Populares de Libertação de Angola (FAPLA); União Nacional Para a Independência Total de Angola (UNITA); Movimento Popular de Libertação de Angola (MPLA); Namibië; Angola; Operasie Modulêr; Operación Saludando á Octubre; Ratel; T-54; T-55, Deon Ferreira; Bok Smit; 61 Gemeganiseerde Batteljon Groep (61 Mech); 47 Brigade.

\section{INTRODUCTION}

On 3 October 1987, a battalion-sized unit of the South African Defence Force (SADF) attacked a brigade of the Angolan army, the Forças Armadas Populares de Libertação de Angola (FAPLA), on the southern bank of the Lomba River in southeastern Angola. What followed, was the biggest mechanised battle on African soil since the demise of the German Afrika Korps in May 1943. 
Although it remains internationally relatively unknown, it was indeed one of the most complete military victories in military history. (This conclusion will be fleshed out in the last section of the article.) FAPLA's 47 Brigade was obliterated and ceased to exist as an organised military formation. The South Africans came out almost unscathed.

This battle also meant the end of FAPLA's grand offensive to crush the Angolan rebel movement, the União Nacional Para a Independência Total de Angola (UNITA). It was of prime importance in the late 20th century history of southern Africa. It was a building-block in the realisation on both sides that war was not the answer and that a political solution was needed through negotiation. This, in turn, became the prototype for the negotiations between the then South African Government and the African National Congress/South African Communist Party (ANC/SACP), resulting in the surrender of power in 1994.

In addition, the battle is a prime example of one side - the SADF - doing almost everything (from a strict professional military perspective) correct, in stark contrast to the amateurish blundering on the Angolan side. As will be seen, the foundation for the victory was laid by the South African moves even before the first shot was fired. As such, from a tactical and operational viewpoint the Battle of the Lomba is worth studying in order to extract professional lessons for mechanised warfare in the African context. It is a study on how two SADF combat groups were tactically handled on a command level.

It would be worthwhile to use the battle as a case study in officers' training courses at military academies. This article is, therefore, meant as study material for that purpose. As such, lessons may be drawn from the battle. These - they will be discussed in more detail later on - include, amongst others, how important it is to manage a battle even before the first shot is fired; the necessity of training; the use of surprise; and the advantages of what is known as "directive control", instead of "detailed control" on the battlefield. Obviously, these lessons have to be supplemented by studying other battles as well, but looking at the handling of the units at the Lomba may prove to be illuminating.

The Battle of the Lomba is largely known through South African eyes. Helmoed-Römer Heitman based the account in his book on certain SADF documents made available to him, ${ }^{1}$ but since then, more archival sources have been declassified which throws new light on the battle. Fred Bridgland did not describe the battle as such, but quoted from three interviews with SADF officers. ${ }^{2}$ In recent years, translated accounts from Soviet advisors on FAPLA's side

1 Helmoed-Römer Heitman, War in Angola. The final South African phase (Gibraltar: Ashanti, 1990), pp. 74-77.

2 Fred Bridgland, The war for Africa. Twelve months that transformed Africa (Gibraltar: Ashanti, 1990), pp. 135-149. 
illuminated what happened on the other side of the hill. ${ }^{3} \mathrm{~A}$ book with contributions from (amongst others) Russian, Cuban, and East German authors about the Border War as such ${ }^{4}$ could have shed light on the "other side's" perspective, but has unfortunately fallen far short of expectations. Hopefully, this article will shed new light on the tactical and operational aspects of the battle.

A word about the sources: This article reflects the view as seen at battalion and brigade level. Eyewitness accounts by participants on grassroots level contribute almost nothing to the bigger picture, as these reflect only what happened in their immediate vicinity. Therefore, a lot of emphasis is placed on information gleaned from archival documents in the SANDF Documentation Centre. At the same time, no Angolan sources could be utilised. The Angolan archives are firmly closed, and no eyewitness accounts from that side have been published. However, one gets a glimpse of the Angolan tactical decision-making process from the SADF intercepts. The Soviet archives are also closed. Some Russian accounts have, however, been published in translated form and these have been used extensively when relevant. It is, therefore, important to realise that the following analysis could have looked different if sources from the other side of the hill had been sufficiently available.

Finally, this article is an offshoot from a book by the author with the title, Ratels on the Lomba: The story of Charlie Squadron. What the battle meant on grassroots level, is decribed there.

A last introductory remark: The Battle of the Lomba refers only to the battlefield confrontation of 3 October 1987 and the events surrounding it. It was part of a broader campaign, generally known as the Battle of Cuito Cuanavale.

\section{BACKGROUND}

The Battle of the Lomba on 3 October 1987 was the turning point of what the South Africans called Operation Moduler and the Angolans Operación Saludando à Octubre - a reference to the Communist Russian Revolution of October 1917. By this time, the Border War, as the South Africans called it, had been waged for more than twenty years. During the first years, 1966-1974, it was a relatively low-key affair. But the Portuguese military coup d'etat of April 1974 changed the strategic situation dramatically.

The new Portuguese regime pulled out of its African colonies. After a brief civil war, the communist-backed Movimento Popular de Libertação de Angola

3 Gennady Shubin (ed.), The oral history of forgotten wars. The memoirs of veterans of the war in Angola (Moscow: Desktop Published, 2007); Gennady Shubin and Andrei Tokarev (eds), Bush War. The road to Cuito Cuanavale. Soviet soldiers' accounts of the Angolan War (Auckland Park: Jacana, 2011).

4 lan Liebenberg, Jorge Risquet and Vladimir Shubin (eds), A far-away war. Angola, 1975-1989 (Stellenbosch: Sun Press, 2015). 
(MPLA) movement took over power in the Angolan capital, Luanda. An abortive South African invasion to prevent that ended in a political catastrophe. In spite of impressive operational and tactical successes, the South Africans lost their international backing and had to withdraw. The Apartheid Government's tentative outreach to African states was fatally affected. ${ }^{5}$

In subsequent years, the communist-backed South West African People's Organisation (SWAPO) used Angolan territory as safe rear areas from whence to cross the border into South West Africa (SWA; today Namibia). The SADF answered with a series of brigade-sized cross-border operations in order to pre-empt the SWAPO infiltration and drive them back some $250 \mathrm{~km}$ into Angola. In the process, SWAPO sought - and got - FAPLA protection, with the result that the SADF at times felt it had to forcibly push FAPLA out of the way to get at SWAPO. ${ }^{6}$

In the meantime, a second war intermeshed with the one between the SADF and SWAPO. South Africa gave military aid to UNITA, as this movement occupied the southeastern corner of Angola and prevented SWAPO guerrillas from entering the territories of Caprivi and Okavango. The SADF military strategy against SWAPO south of the border centered around limiting the insurgency war as far as possible to the relatively small area of Ovambo, making it easier to contain the insurgency. Thus, UNITA's occupation of the southeastern corner of Angola was crucial to the SADF strategy. ${ }^{7}$

However, over the years, the SADF was increasingly sucked into the war between the MPLA and UNITA. Seen from the South African viewpoint, it could not afford to lose UNITA as a shield against SWAPO. Therefore, in 1985 and 1986 the SADF was forced to send in troops clandestinely to help ward off big FAPLA offensives. ${ }^{8}$ In 1987 the same happened again, and that is how a SADF formation came to be pitted against an overwhelming FAPLA offensive.

The FAPLA 1987 battle plan was actually very unimaginative and it essentially remained the same as the previous two: The offensive forces would move from Cuito Cuanavale in the north to the south and southeast towards

5 See F du T Spies, Angola. Operasie Savannah 1975-1976 (Pretoria: SA Weermag Direktoraat Openbare Betrekkinge, 1989); Sophia du Preez, Avontuur in Angola. Die verhaal van Suid-Afrika se soldate in Angola 1975-1976 (Pretoria: Van Schaik, 1989); Peter Stiff, The silent war. South African Recce operations 1969-1994 (Alberton: Galago, 1999), ch. 9; Willem Steenkamp, South Africa's Border War 1966-1989 (Gibraltar: Ashanti, 1999), pp. 36-74; Willem Steenkamp, Borderstrike! South Africa into Angola 1975-1980 (s.l.: Just Done, 2006), pp. 60-206; Hilton Hamann, Days of the generals. The untold story of South Africa's apartheid-era military generals (Kaapstad: Zebra, 2001), ch. 1, 2. The Cuban side of the story is told by Piero Gleijeses, Conflicting missions. Havana, Washington, Pretoria (Alberton: Galago, 2003).

6 See Leopold Scholtz, The SADF in the Border War 1966-1989 (Cape Town: Tafelberg, 2013), ch. 5-8.

$7 \quad$ lbid., ch. 9.

8 Ibid., ch. 10. 
the Lomba River, cross it and occupy the town of Mavinga. Mavinga was operationally important because of its airstrip, which would enable the Angolan Air Force to support a further phase in the offensive, an advance to Jamba, UNITA's headquarters. Once Jamba fell, the expectation was UNITA would be finished. ${ }^{9}$

Because the South Africans felt that UNITA's survival was vital to their containment of SWAPO's insurgency inside SWA, they felt they had to come to UNITA's aid. The decision-making process in this regard, however, was haphazard and incremental, reflecting their unwillingness to be sucked too deeply into the Angolan civil war. ${ }^{10}$ In the end, an objectively speaking much too small force for the job was given permission to cross the border into the Angolan province of Cuando Cubango.

\section{THE OPPOSING ORDERS OF BATTLE}

For the 1987 offensive, FAPLA employed a total of eight brigades. Of these, two were employed as escorts for the vital supply convoys moving between Menongue (at the end of a long railway line to the harbour town of Namibe) and Cuito Cuanavale. A third acted as the garrison of Cuito Cuanavale (where the FAPLA operational headquarters were situated), and a fourth occupied the rear area at Tumpo just opposite the Cuito River. The other four formed the main mailed fist of the offensive. ${ }^{11}$

These four brigades advanced in two groups of two so that they could afford mutual support. To the east were 15 and 21 Brigades; more westwards they were joined by 47 and 59 Brigades. This force comprised about 6000 men and 80 tanks, plus artillery, augmented with air support in the form of (according to Western intelligence estimates) 30 MiG-23s, 50 MiG-21s, 8 Sukhoi-22 and various obsolete types, as well as numerous anti-aircraft gun and missile batteries. ${ }^{12}$

An Angolan brigade was modelled on a Soviet brigade, and therefore considerably smaller than a normal NATO or British brigade, which in turn was the basic model for the SADF. According to Major-General Roland de Vries, a typical FAPLA brigade was about 1500 men strong and consisted of the following:

$9 \quad$ Ibid., p. 253.

10 Ibid., ch. 12; Leopold Scholtz, "Suid-Afrika se strategiese posisie en die 'Slag van Cuito Cuanavale', 1987-1988”, Journal for Contemporary History 37(2), December 2012, pp. 165-190.

11 Scholtz, The SADF in the Border War, p. 265.

12 South African National Defence Force (SANDF) Documentation Centre. "Lesse geleer tydens konvensionele operasies in die westelike subteater", Inleiding, Aanhangsel A, par. 5 (document provided by Major-General Roland de Vries); Group 4, Box 160, HS Ops/UG/314/4/3, HSAW 3 - HSAW, 21 August 1989; Bridgland, p. 15. 
- Three motorised infantry battalions, transported in armoured personnel carriers, such as BTR-60s or BTR-152s, or Ural military trucks. Each battalion had three rifle companies with three platoons each and support weapons - light machine guns, $60 \mathrm{~mm}$ mortars and shoulder-launched RPG-7 anti-tank missile systems. Each battalion also had a mortar platoon with six $82 \mathrm{~mm}$ mortars, an anti-tank platoon with six B-10 recoilless guns or Sagger anti-tank missiles, as well as a grenade launcher platoon with six AGS-17 launchers;

- One tank company, called a tactical group (FAPLA's equivalent of a South African squadron), with 10 T-54 and/or T-55 main battle tanks;

- One artillery battalion (SADF: regiment), organised into six batteries. Two of these were equipped with six D-30 guns of $122 \mathrm{~mm}$ calibre; two with older $76 \mathrm{~mm}$ ZIS-3 guns, another with BM-21 multiple rocket launchers, and one with six $120 \mathrm{~mm}$ mortars;

- $\quad$ One reconaissance company with PT-76 amphibious tanks and BRDM-2 armoured reconnaissance vehicles; and

- An air defence platoon with various anti-aircraft missiles and guns. ${ }^{13}$

However, the Angolan 47 Brigade, which would be the defending force on 3 October, was somewhat stronger than the others in that it had, according to a Soviet source, a tactical group of 22 tanks (T-54s and/or T-55s). ${ }^{14}$ (In fact, after the battle, when the South African troops tried to reconstruct it among themselves, they actually counted 28 tanks in the Angolan force. ${ }^{15}$ This may, of course, be an exaggeration as some tanks may have been counted more than once.) To begin with, 47 Brigade and its Tactical Group was about 1400 men strong. ${ }^{16}$ However, during September, the South African bombardments, UNITA action and natural causes - disease, desertion and the like - whittled the number steadily down. By 22 September, according to a SADF document (presumably based on the SADF intercepts of FAPLA radio communications ${ }^{17}$ ), the brigade had lost 270 dead and 200 wounded. In addition, it had lost two of its tanks. ${ }^{18}$

13 Roland de Vries, Eye of the firestorm. Strength lies in mobility (Cape Town: Naledi, 2013), p. 640 .

14 Shubin (ed.).

15 Leopold Scholtz Private Collection. Diary of 2nd Lieutenant Len Robberts, 2IC of Charlie Squadron, 5 October 1987.

16 Bridgland, p. 126.

17 Garrett Ernst Eriksen, Forged in flames: The SADF experience of the Battles of Cuito Cuanavale 1987-1988 (History honours thesis, Rhodes University, 2010), p. 47, available at, <www.scribd.com/doc/48564518/Forged-in-Flames>.

18 SANDF Documentation Centre. JF Huyser Collection 27/122, “16 Sep 87 (Attack by 61 Meg Bn Gp)", s.a.; JF Huyser Collection 40, Major Walter Dorning, "A concise history of Operation Moduler", p. 68. 
Both the whole FAPLA force involved in the advance and 47 Brigade on its own may thus be thought to be a formidable force indeed.

MAPO2: Battles at the Lomba

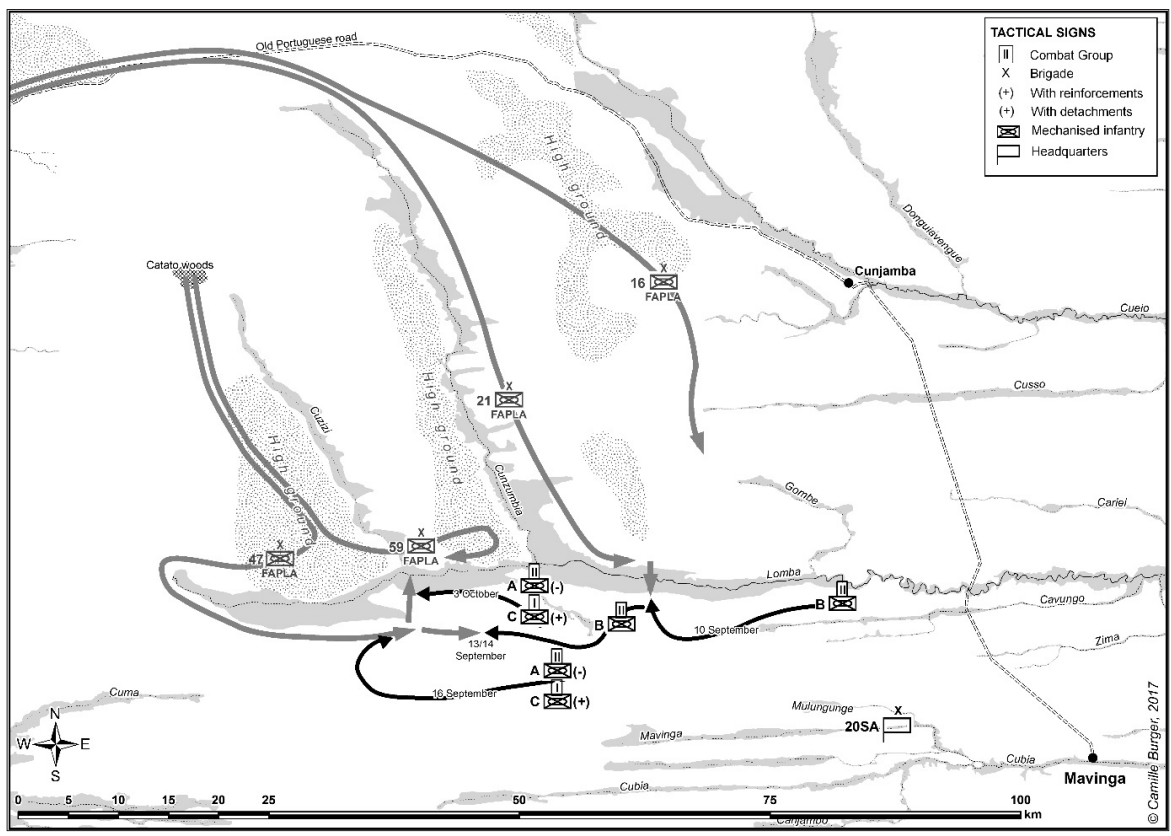

Cartography: Camille Burger

On the other hand, the SADF's theoretical brigade structure would mirror that of NATO or the British Army, consisting of three battalion-sized units, an artillery regiment and various other support troops. In practise, the structure of the SADF brigade-sized ad hoc-formations were mostly dependent on the demands of the operations they were formed for. In this case, the formation set up to structure the South African force was named 20 SA Brigade, and put under the command of an able infantry officer, Colonel Deon Ferreira. As past Officer Commanding 32 Battalion, Ferreira had considerable operational experience in Angola.

Ferreira had only a small force at his disposal. This comprised 61 Mechanised Battalion Group (more about this unit, generally known as 61 Mech, a little later), two motorised infantry companies from 32 Battalion (plus its anti-tank squadron, consisting of four Ratel-90 armoured cars and four Ratels equipped with the still experimental ZT3 anti-tank missile), as well as two motorised infantry companies from 101 Battalion. There were also three artillery batteries, one each of the formidable $155 \mathrm{~mm}$ G-5 Howitzer, the devasting Valkiri 
$127 \mathrm{~mm}$ multiple rocket launcher, and $120 \mathrm{~mm}$ mortars. The whole force was 2609 men strong. ${ }^{19}$

In addition, there were an unknown number (probably several thousand) of UNITA fighters alongside the South Africans. But, as these were neither trained, equipped, nor structured for high-intensity mechanised warfare, their military value on a conventional battlefield was, at best, dubious. They were, however, much better in guerrilla warfare, where they frequently gave FAPLA a good run for their money. This meant that their role in Operation Moduler in general, and the 3 October battle in particular, was at best secondary.

Before we turn to the South African order of battle, a few words about 61 Mech, which formed the mainstay of the SADF assault force on 3 October. This was an all-arms unit, consisting of two mechanised infantry companies and an armoured car squadron. The infantry companies were equipped with the extremely mobile Ratel infantry fighting vehicle and its rapid-firing $20 \mathrm{~mm}$ cannon. Alpha Company included a mortar group $(81 \mathrm{~mm})$, and Bravo the anti-tank platoon with its eight Ratel-90 armoured cars and another mortar group (60 mm). Charlie Squadron (12 Ratel-90s) also included the sapper platoon. In theory, 61 Mech also included an Olifant tank squadron, but for some unfathomable reason this sub-unit was not mobilised and not present on the battlefield on the fateful day when the forces locked horns in the Battle of the Lomba. ${ }^{20}$

In order to retain maximum flexibility and still have a reserve, Ferreira had to juggle his understrength brigade. He created three composite combat groups:

- Combat Group A (under the command of Commandant - Lieutenant Colonel - Kobus "Bok" Smit, OC 61 Mech). This consisted of Alpha Company and Charlie Squadron of $61 \mathrm{Mech}$, as well as Golf Company of 32 Battalion (motorised infantry);

- Combat Group B (Commandant Robbie Hartslief): Two companies from 101 Battalion, one from 32 Battalion (all three being motorised infantry), and the latter unit's anti-tank squadron;

- Combat Group C (Major Dawid Lotter): Bravo Company (61 Mech), including the anti-tank platoon which would be utilised as an additional armoured car squadron; and

- An artillery regiment as decribed above..$^{21}$

19 SANDF Documentation Centre. JF Huyser Collection 15/55, Op Moduler - Logistiek, s.a. [beginning of October, 1987].

20 Cf. Willem Steenkamp and Helmoed-Römer Heitman, Mobility conquers. The story of 61 Mechanised Battalion Group 1978-2005 (Solihull: Helion, 2016), pp. 127-128; Leopold Scholtz, Ratels on the Lomba. The story of Charlie Squadron (Johannesburg: Jonathan Ball, 2017), ch. 3.

21 SANDF Documentation Centre. JF Huyser Collection 40, Major Walter Dorning, p. 42. 


\section{THE OPENING MOVES}

Early in 1987, South African Military Intelligence started getting indications that FAPLA was preparing a new offensive in what was becoming a predictable yearly event. The South African Government and SADF High Command unwillingly approved, once again, the incremental commitment of limited forces to stop the offensive. The offensive, a mostly slow and cumbersome affair, started on 14 August with an advance of no more than $4 \mathrm{~km}$ a day, which gave the South Africans ample time to react. This, however, was also slow, and the final decision to release all the forces named above was only taken on 28 August. By then, the 32 and 101 Battalion elements, together with some artillery, were already in Angola, but not yet engaged in fighting. 61 Mech crossed the border on 1 September and reached the vicinity of Mavinga six days later. ${ }^{22}$

On the Angolan side, 15 and 21 Brigades approached the northern banks of the Lomba opposite Mavinga by 9 September, looking for places to cross the river. Further westwards, 47 and 59 Brigades advanced in a pincer movement: While 47 rounded the western source of the river and moved eastwards along the southern shore, 59 moved in conjunction with 47 on the northern side. Apparently they were looking for a ford so that 59 could join forces with 47 across the river. The brigade moved westward with some difficulty through the dense bushes. But by 6 September, it had moved no more than $6 \mathrm{~km}$ from the source of the Lomba before it collided with a South African special forces team. It then called a halt and fortified itself in an impregnable dense piece of jungle. ${ }^{23}$

The week that followed was crucial. On 9 and 10 September 21 Brigade tried to establish a bridge-head on the south side of the Lomba. This was detected by Commandant Robbie Hartslief (Combat Group B), who counterattacked at once with two motorised infantry companies and 32 Battalion's anti-tank squadron, equipped inter alia with the experimental ZT3 anti-tank missile. In the event, the FAPLA attempt was rebuffed with considerable loss of life and three tanks, all destroyed with the new missiles. ${ }^{24}$

However, the presence of 47 Brigade, the strongest of the enemy formations, south of the Lomba was dangerous. Not knowing enough about the Angolans' plans, Ferreira had to plan for the worst scenario, namely 47 and 59 joining forces and advancing on to Mavinga, while 15 and $21 \mathrm{kept}$ the South Africans occupied to the east. 47 Brigade, therefore, simply had to be neutralised, almost at all cost.

While the newly-arrived Combat Group A were still acclimatising, B was thrown against 47 Brigade to eliminate the threat. Thus, Hartslief attacked with

22 Scholtz, Ratels on the Lomba, pp. 67-70.

23 SANDF Documentation Centre. JF Huyser Collection 40, Major Walter Dorning, pp. 46-47.

Ibid., pp. 50-52. 
his force, with Dawid Lotter's Combat Group C in reserve, on 13 September. But the terrain was extremely difficult. It was simply impossible to reach the Angolans, let alone to destroy them. After a while, the attack had to be called off. ${ }^{25}$

Therefore, Ferreira decided to hand the reigns to Bok Smit and Combat Group A, again with $C$ in reserve. To cut a long story short, once more the extremely dense bush shielded the Angolans and made any attempt to either drive them out, or to destroy them utterly futile. This attempt also failed. ${ }^{26}$

On 18 and 19 September, 21 Brigade made renewed attempts to cross the river at the same spot as its failed attempt of 10-11 September. They failed just as disastrously. ${ }^{27}$

\section{THE OPERATIONAL SITUATION, END OF SEPTEMBER}

If we want to understand the coming battle of 3 October, we will first have to review the operational situation at the end of September 1987. The late Major Walter Dorning, official SADF chronicler of Operation Moduler's first phase, viewed it thus in hindsight, "Viewed from a still wider perspective, it is in retrospect clear that the battles of the week 7-13 September marked the turning point in the entire operation. By failing to establish a bridgehead on the southern banks of the Lomba, the enemy had missed the chance of achieving a decisive breakthrough and establishing a tactical platform for an advance on Mavinga itself. After the battles of 7-13 September, the initiative passed firmly from the enemy to the SADF forces, with the FAPLA brigades increasingly on the defensive." 28

At the time, this was of course not entirely clear. Seen from Ferreira's perspective, and looking through his eyes with the information at his disposal, 47 Brigade's position remained potentially dangerous. It remained necessary to remove the danger.

Ferreira had two relatively good sources of information. One was the SADF's excellent radio interception service. In the SANDF Documentation Centre there are several documents detailing intercepted FAPLA messages between its tactical headquarters in Cuito Cuanavale and 47 Brigade. ${ }^{29}$

25 Scholtz, The SADF in the Border War, pp. 271-273; Heitman, pp. 53-55; Bridgland, pp. 74-81; DH Lotter: Bravo Company plus Anti Tank Platoon 1987 (E-book, privately published by Dawid Lotter, 2013), pp. 87-102.

26 Scholtz, The SADF in the Border War, pp. 269-272; Scholtz, Ratels on the Lomba, ch. 1,5 .

27 Scholtz, The SADF in the Border War, p. 273.

28 SANDF Documentation Centre. JF Huyser Collection 40, Major Walter Dorning, pp. 55-56.

29 Cf. for instance, SANDF Documentation Centre. JF Huyser Collection 27/122, "16 Sep 87 (Attack by $61 \mathrm{Meg} \mathrm{Bn}$ )", s.a.; JF Huyser Collection, intercepted messages, 3 October 1987; JF Huyser Collection 26/106, Interview with Commandant Smith, SO1 Intelligence, 8 December 1987. 
The second was Major Pierre Franken, a brave forward artillery observer who, for days on end, was sitting perched in a tree on the northern bank of the Lomba to direct artillery fire by radio. He had a bird's eye view of the vicinity and reported all moves that he could see to Ferreira and Bok Smit. ${ }^{30}$

Neither attempt to dislodge 47 Brigade from its fortified position in its jungle fortress south of the Lomba on 13 and 16 September succeeded. When seen purely from a tactical viewpoint, both were actually dismal failures. Operationally, they were in fact quite important.

On the one hand, they proved that the Brigade's position was utterly unassailable as long as it stayed in its positions. Therefore, Ferreira wisely decided not to renew an attempt with no hope of success, and to stand down. On the other, it also proved that the formation was isolated. 59 Brigade was frantically marching to and fro on the northern side of the river like a caged beast looking for a gap, but there was none. At the same time, Ferreira continued his ongoing artillery and aerial bombardment of 47 Brigade in order to wear them out, day by day, bit by bit, until their ammunition, food and fuel would start to run out. As it was, the Angolan formation was dead in the water.

In hindsight, we can reconstruct how Ferreira brilliantly stage-managed the opening moves of the battle which would take place only several days later. Ferreira's tactics, as Fred Bridgland describes it (presumably on the basis of an interview with Ferreira), "was to exhaust the brigade and draw it into a 'killing ground' where the advantage would be with his small force which, like the Boer armies of old, aimed to keep the enemy off balance with fast-moving, unorthodox and aggressive manoeuvres until FAPLA began to make major mistakes". ${ }^{31}$ And indeed, on 20 September Ferreira ordered Bok Smit to be ready, "to destroy 47 and 59 Brigades as soon as they move into a selected and reconnoitred killing ground". The South Africans started reconnoitring along the Lomba in order to find such a suitable "killing ground", a central pillar in the SADF mobile operational and tactical approach adopted since the seventies. ${ }^{32}$

At Army headquarters, the Chief of the Army, Lieutenant General "Kat" Liebenberg, showed himself to be somewhat nervous about 47 Brigade's continued presence south of the Lomba. He wrote to Ferreira, expressing the fear that 47 Brigade's presence south of the Lomba could be the springboard for a renewed FAPLA offensive to take Mavinga. Therefore he ordered, "[a] military decision must be forced ASAP [as soon as possible] in the Sixth Military Region [the province of Cuando Cubango, where the fighting raged]". Thus, 47 Brigade, "must be eliminated as a factor in the offensive". ${ }^{33}$

$30 \quad$ Bridgland, pp. 128-136.

31 Ibid., p. 122.

3261 Mech Online Archive. 20 Brigade - Tak HK, 20 September 1987, available at, <http:// www.61mech. org.za/uploads/mediafiles/files/232.pdf>.

33 SANDF Documentation Centre. JF Huyser Collection 15/24, H Leër - H Leër S Ops, 30 September1987. 
It is very interesting to follow the next few days' events, almost like a deadly chess game with both players making moves and trying to force the other's hand. In order to escape from its isolation and the steadily frittering away of its strength and supplies by the unrelenting South African artillery and air bombardment, 47 Brigade tried to build a TMM bridge (a mobile bridge, designed in the Soviet Union) over the Lomba. The South African shelling soon put a stop to that. ${ }^{34}$

On 28 September, 20 SA Brigade intercepted an interesting exchange of messages between the leadership of 47 Brigade and FAPLA's operational headquarters in Cuito Cuanavale. The commander of 47 Brigade received an order to leave the safety of his jungle fortress and to start marching eastwards towards Mavinga. This village, which was after all the primary objective of the whole offensive, was about $70 \mathrm{~km}$ away. Cuito Cuanavale felt that the brigade should be able to reach it, being the strongest of the four FAPLA brigades on the front line. ${ }^{35}$

This order proved how far those giving the orders at the Cuito Cuanavale headquarters were removed, not simply from the battlefield, but from reality. It seems logical to assume that their insights were derived from looking at a map, instead of envisaging the real conditions at the front.

However one looks at it, this fitted exactly in Ferreira's operational approach. Moving out of its jungle position, 47 Brigade would come into more open territory where the SADF's forté, its mobile warfighting capacity, would come into its own. From Ferreira's vantage point, his patience was paying off, and things were slowly coming together. He put 61 Mech on notice, "to act when the [FAPLA] convoy crossed the Lomba just West of Cunzumbia confluence". 36

Of course, the 47 Brigade commander had a much better understanding of his force's problems than Cuito Cuanavale. He replied, quite correctly, that his supplies - especially his fuel - was inadequate and getting less all the time. Then he was threatened: Either comply with the order, or face a court martial. ${ }^{37}$

But on 1 October saner views prevailed in Cuito Cuanavale. The previous orders were rescinded. 47 Brigade was now told to finish the TMM bridge over the Lomba, cross the river to the northern side and join the other FAPLA forces.

34 SANDF Documentation Centre. JF Huyser Collection 26/106, Interview with Commandant Smith, SO1 Intelligence, 8 December 1987; Lotter, p. 111.

35 SANDF Documentation Centre. JF Huyser Collection 26/106, Interview with Commandant Smith, SO1 Intelligence, 8 December 1987; Lotter, p. 111.

36 SANDF Documentation Centre. JF Huyser Collection 23/92, Situation report, 24 September 1987.

37 SANDF Documentation Centre. JF Huyser Collection 26/106, Interview with Commandant Smith, SO1 Intelligence, 8 December 1987; Lotter, p. 111. 
Then the combined force would once again force a crossing southwards and march on Mavinga. ${ }^{38}$

In his headquarters near Mavinga, Deon Ferreira followed the exchange with growing interest. He knew that 47 Brigade's time was running out in its impenetrable hide, but he also had to face the possibility that the enemy could break out of its isolation by themselves. Indeed, on the morning of 30 September he received the news that 47 Brigade had at last made contact with 59 Brigade. An advance party had transferred a number of seriously wounded soldiers and had received a small quantity of food and ammunition. ${ }^{39}$

Was this the first phase of 47 Brigade's escape? Or was it an isolated development?

Luckily for Ferreira, clarification was received soon afterwards. Reports indicated that 47 and 59 Brigades were collaborating in the construction of a TMM bridge just east of the confluence of the Lomba and Cuzizi Rivers - in other words, some distance eastwards of 47's jungle position. ${ }^{40}$

This enabled Ferreira to have an idea of where 47 Brigade would be heading next. He now knew that the chosen crossing point would be in less bushy terrain, which suited him just fine. What he did not know, of course, was whether 47 Brigade was about to cross the river northwards, or whether 59 Brigade would come southwards. Whatever the case, Ferreira realised that the die was cast. It was now or never. D-Day was fixed for 5 October, the day on which the enemy was expected to reach the crossing point. In the meantime, he ordered an intensification of the artillery and aerial bombardments to spur the Angolans on. ${ }^{41}$

Several additional pieces of information confirmed what he deduced. Firstly, his Electronic Warfare Division intercepted Cuito Cuanavale's orders to the 47 Brigade commander to move northwards over the river and join 59 Brigade. And then on 2 October, Major Pierre Franken, still sitting in a tree overlooking the Lomba, reported that 47 Brigade was on the move and in the open. He told Ferreira that the enemy was establishing a temporary base area, 4-6km south of the TMM bridge at the confluence of the Lomba and Cuzizi. More than 100 vehicles were concentrating south of the bridge, which had been completed on the afternoon of 2 October. North of the river, three tanks from 59 Brigade were

38 SANDF Documentation Centre. JF Huyser Collection 26/106, Interview with Commandant Smith, SO1 Intelligence, 8 December 1987, paragraph 20.

39 SANDF Documentation Centre. JF Huyser Collection 40, Major Walter Dorning, p. 73; Bridgland, p. 128.

40 SANDF Documentation Centre. JF Huyser Collection 40, Major Walter Dorning, p. 73; Bridgland, p. 128.

41 SANDF Documentation Centre. JF Huyser Collection 40, Major Walter Dorning, p. 73; Bridgland, p. 128; Kobus Smit, "Operasie Moduler". In: Jannie Geldenhuys (ed.), Ons was daar. Wenners van die oorlog om Suider-Afrika (Centurion: Kraal, s.a. [2012]), p. 226. 
on standby to help if needed. And lastly, UNITA sent a message at 13:00 that two wooden bridges across the Lomba were already completed, with space for a TMM bridge in between. ${ }^{42}$

The news was dramatic. In fact, the Angolans were playing exactly into Ferreira's hand. The terrain was relatively open and suitable for a mechanised attack. The South African commander could not be more pleased. But the news accelerated his plans. If he waited until 5 October, as planned, the bird would have flown. He conferred with Bok Smit and decided to attack the very next day. He did not ask permission from higher headquarters. About a year afterwards, he told Fred Bridgland that, "it was a question of either letting them go or taking a chance. I decided that Bok Smit should take them on. I took the decision on my own without referral to higher level. If we had failed, my army career would have been finished." ${ }^{43}$ (In fact, Ferreira informed Rundu HQ only at 09:35 on the morning of 3 October, after the battle had commenced. ${ }^{44}$ )

\section{THE SADF TACTICAL PLAN}

The idea was to attack early on the morning of Saturday, 3 October. The South African battle plan, as agreed upon between Deon Ferreira and Bok Smit, called for an advance by Combat Group A from east to west, alongside the wide Lomba flood plain. The three troops of 61 Mech's armoured car squadron (Charlie) - 12 Ratel-90s - would be in front in extended line, preceded by a UNITA light infantry screen, whose task it would be to flush out the enemy and then leave them to the better equipped South Africans. Hot on the heels of the armoured cars would come a mechanised infantry company (Alpha, $61 \mathrm{Mech}$ ), whose firepower would be buttressed by $81 \mathrm{~mm}$ and $60 \mathrm{~mm}$ mortars. At the back a motorised infantry company (Golf) from 32 Battalion would follow to mop up after the battle. ${ }^{45}$

To the left of this force, Combat Group $C$ would move forward in conjunction with A. This force included Bravo Company, $61 \mathrm{Mech}$, as well as the eight Ratel90s from the unit's antitank platoon, positioned behind each other from front to back. Their task was to act as a reserve and cover the attacking force from intervention by what was thought to be the bulk of 47 Brigade in its temporary base a few kilometres to the south. Even further to the left were some more UNITA light infantry to warn the South Africans if the enemy advanced from that

42 SANDF Documentation Centre. JF Huyser Collection 28/135, Combat Group Alpha - 20 Brigade HQ, 2 October 1987; JF Huyser Collection 40, Major Walter Dorning, pp. 74-75; Bridgland, p. 133-134, 162; Lotter, pp. 111-112.

43 SANDF Documentation Centre. JF Huyser Collection, Major Walter Dorning, pp. 74-75; Bridgland, pp. 133-134, 162; Lotter, pp. 111-112.

4461 Mech Online Archive. 20 Bde HQ - Tac HQ Rundu, 3 October 1987, available at <http://www.61mech.org.za/uploads/mediafiles/files/232.pdf>. Ibid. 
side. ${ }^{46}$ Having overwhelmed the advance party in the vicinity of the crossing site, the attackers would then wheel left and move southwards towards the main enemy force, the order stated. ${ }^{47}$

MAPO4: 3 October 1987

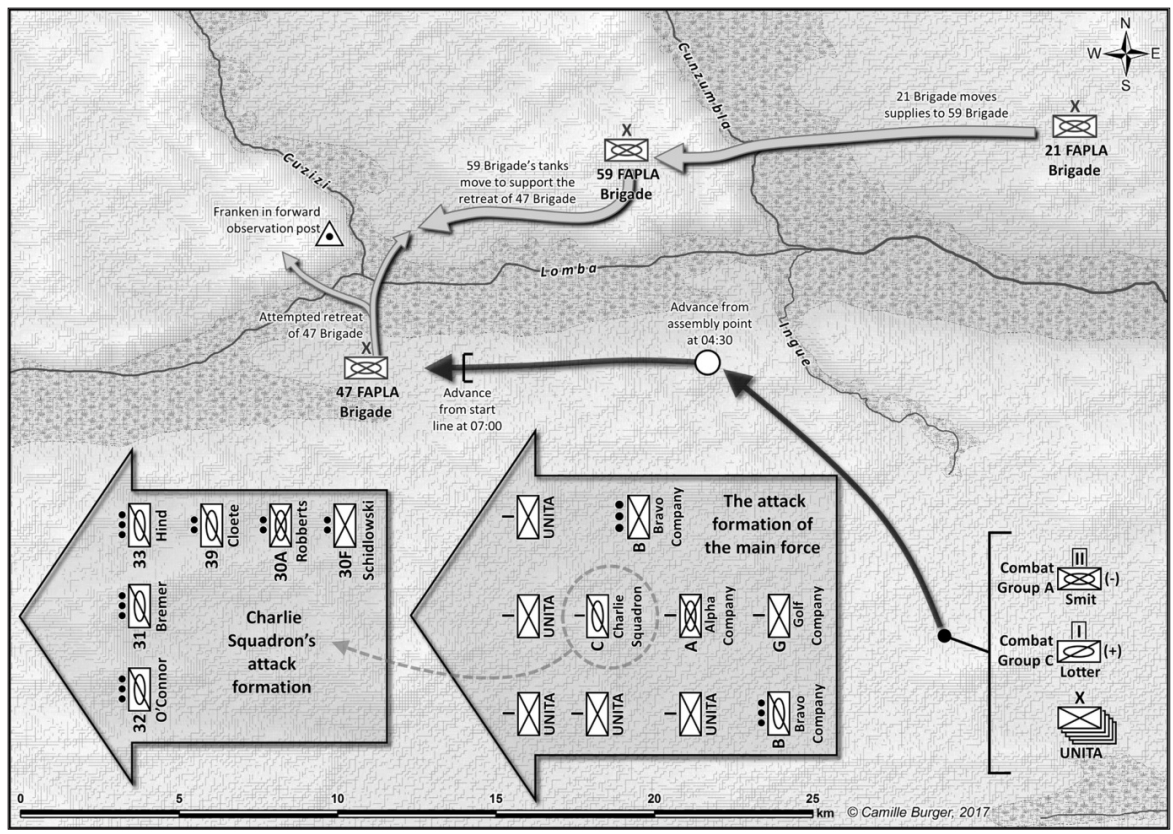

Cartography: Camille Burger

This battle plan was clearly based on the assumption that the bulk of 47 Brigade would still be at its temporary base a few kilometres south of the crossing point, and that only an advance party would be at the crossing point itself, safeguarding the area for the arrival of the rest of the brigade. Provided the assumption was correct, it fulfilled every sound tactical principle. The initial point of attack would be where the enemy was weak, not strong. Then the main force would be cut off from the crossing and destroyed in detail. It was an excellent plan - on condition that the practical situation at the time of contact was as Ferreira and Smit were told it would be. 


\section{THE BATTLE}

The problem is - it was not. In fact, the South Africans' information was all wrong, although their commanders did not know it yet.

The South Africans were formed up before first light on the morning of 3 October and started their westward advance, with their right wing resting on the southern bank of the Lomba, as planned. At between 08:30 and 09:10 - the sources differ - the Ratel-90 on the extreme right wing, commanded by Corporal Duncan Taylor, came across the first enemy and fired the first shot. The Battle of the Lomba had started. ${ }^{48}$

It soon became clear to the Ratel-90 crews that they had clashed with a far stronger force than they had been led to believe would be present at the initial point of contact. In fact, long before first light and unknown to the South Africans, 47 Brigade had moved out from its temporary base a few kilometres south of the crossing point, and was actually present at the TMM bridge in full strength. This meant, in principle, that Ferreira and Smit had miscalculated badly.

Within a few minutes, a furious armoured battle broke out. For the South African commanders, this was a crucial moment. They basically had two choices: They could either pull back as their forces were clearly heavily outnumbered and outgunned by the enemy, or they could bite the bullet and press on.

Unfortunately, we do not possess a record - if any exists - of radio messages at this stage between Ferreira and Smit. We also do not possess a proper record of how Ferreira judged the situation, beyond what Fred Bridgland wrote in his book about the campaign on the basis of an interview with Ferreira. ${ }^{49}$ Ferreira has since passed away; so his version of events went with him to the grave. And Smit's version ${ }^{50}$ does not throw much light on what Ferreira thought of things.

Nevertheless, when one reviews both forces' advantages and disadvantages at this moment, we may perhaps see - if only in hindsight - why the South Africans correctly decided to continue the attack.

First of all, Combat Group A had the considerable advantage of surprise. Until the shooting began, the Angolans had no inkling of the South Africans' presence. As the classical Chinese war philosopher Sun Tzu wisely wrote centuries ago, "Attack when they are unprepared, make your move when they do not expect it". ${ }^{1}$

48 The description and analysis of the battle is taken from Scholtz, Ratels on the Lomba, ch. 8, 9 .

49 Bridgland, pp. 133-134, 162.

50 Smit, pp. 221-228; Kobus Smit, "Personal impressions of the Commander", available at, <http://www.61mech.org.za/operations/operation-modular>.

51 Sun Tzu, The art of war, translated by Tomas Cleary (Boston: Shambhala, 1988), p. 54. 
Secondly, the South Africans forcibly collided with the enemy while the latter were moving. FAPLA, a relatively chaotic and disorganised force at best, could at times resist steadfastly when properly prepared in strong defence lines, although even then, they could never hold against a determined SADF attack. But in this case, they were on the move. In the kind of mobile battle which now developed, the South Africans were very good. Such a battle takes a capacity to think fast on your feet and react like lightning to unexpected situations - for which the SADF rank and file were well-trained, and the Angolans not. Lastly, the South African attackers collided with 47 Brigade's right flank. Any flank is at best a very vulnerable place.

From this short analysis, it should be obvious that the Angolan advantage of superior numbers, weapons and firepower was obviated by the South Africans' superior nimbleness and mobility. In actual fact, they had everything going for them, provided they kept their nerve and press home their advantage. Which is exactly what they did. The crews of Charlie Squadron's armoured cars fought like automatons, their harsh training kicking in. They simply did everything they were trained for, and more. On the other side, the understandable immediate reaction was a panic-stricken flight. So chaotic was this flight, that the TMM bridge was blocked, and 47 Brigade's only way of escape was closed. After this, FAPLA for a while fought back with considerable courage.

But it was a carnage. Twice the SADF armoured cars' ammunition ran out, and they had to pull back to rearm and refill the gas necessary for the recoil action of their $90 \mathrm{~mm}$ guns. Both times the decision was taken by Bok Smit, being the officer on the spot, without asking permission from Deon Ferreira. This was in accordance with normal SADF battlefield procedure, giving great scope to commanders on the ground, as long as they stay within the parameters previously given down from above. During both pauses, the South African artillery took over and rained death and destruction on the Angolans.

After the first pause, one Ratel-90, commanded by Second Lieutenant Adrian Hind, was shot out by an enemy tank. Hind was grievously wounded and died, while his two crew members, cavalrymen Kurt Oelofse and Glen Woodhouse, as well as Second Lieutenant Michael O'Connor in a separate incident, were wounded and flown out by helicopter.

For the third and final charge, Smit put the fresh eight Ratel-90's of the anti-tank platoon at the front. This attack finally broke 47 Brigade's back. Those still alive broke and ran for their lives towards the river, where the South Africans mowed them down in their hundreds until Bok Smit took pity on them and stopped the bloodshed. 47 Brigade, for all practical intents and purposes, ceased to exist.

The statistics tell a story. The South Africans lost one dead and four serious wounded that had to be flown out, plus a similar number of lightly wounded who were patched up and sent back into battle. Nobody knows exactly how many 
Angolans died. Captain Herman Mulder, 61 Mech's Portuguese-speaking intelligence officer who listened to the anguished FAPLA radio messages, told Fred Bridgland that the Angolans must have lost some 600 soldiers dead and many more wounded..$^{52}$ It sounds plausible. When I interviewed Mulder while researching my book about Charlie Squadron, I asked him what he based his estimate on. His short answer was, "I saw half of them being killed." ${ }^{3}$ UNITA's casualties was never recorded, but, seeing that their role was very limited, it must have been light.

The final statistics of enemy equipment lost was sent to SADF and Army $\mathrm{HQ}$ a few days afterwards: ${ }^{54}$

- $\quad 3 \times$ T-55 tanks destroyed;

- $\quad 18 \times$ T-54 (four recovered, the others destroyed or rendered unserviceable);

- $2 \times$ tank recovery vehicles;

- 26 x BTR-60 armoured personnel carriers;

- 4 x SA 8 anti-aircraft missile systems (one recovered, three destroyed);

- $2 \times$ Surface to air missile carriers (one recovered, one destroyed);

- 1 x Flat Face radar (recovered);

- 3 x BMP-1infantry fighting vehicles (two recovered, one destroyed);

- $6 \times$ ZSU-23 anti-aircraft guns (four recovered, two destroyed);

- $3 \times$ D-30 artillery pieces (122 mm);

- 83 x logistical vehicles (45 recovered, 35 destroyed).

On 14 October, Igor Zhdarkin, a Soviet advisor with the FAPLA forces, jotted down fairly similar statistics in his diary, given to him by Soviet advisors with 47 Brigade: 18 tanks, 20 armoured troop carriers, four D-30 $122 \mathrm{~mm}$ guns, three BM-21 rocket launchers, four Osa-AK anti-aircraft mobile rocket launchers, two Osa-AK transport cars, one P-19 radar station, and various other vehicles. ${ }^{55}$ According to the Soviet commander-in-chief in Angola, General Pyotr Gusev, only, "several tanks, infantry combat vehicles and five anti-aircraft missile systems" survived. ${ }^{56}$ On the South African side it was estimated that 47 Brigade

\section{Bridgland, p. 141.}

53 Interview with Herman Mulder, 14 April 2016.

54 SANDF Documentation Centre. JF Huyser Collection 15/51, H Leër - HSAW, 12.10.1987.

55 Igor Zhdarkin, "Cuito Cuanavale: Notes from the trenches". In: Gennady Shubin and Andrei Tokarev (eds), p. 41.

56 Pyotr Gusev, "Search for your destiny". In: Sue Onslow and Anna-Mart van Wyk (eds), Southern Africa in the Cold War, post-1974 (Washington, D.C.: Wilson Center, 2013), p. 147. 
had lost $93 \%$ of its equipment. ${ }^{57}$ As Major-General Roland de Vries put it, "Within the context of manoeuvre warfare the Battle of the Lomba on 3 October was a decisive turning manoeuvre". ${ }^{8}$

\section{THE CONSEQUENCES}

Although it is impossible at this stage to ascertain 47 Brigade's exact casualty figure, it is certain that the formation ceased to exist. One of 61 Mech's soldiers who saw the battlefield a day or two later, Conrad Farrell, told me in an interview that he saw numerous burnt out and abandoned tanks, lighter armoured vehicles, and many human bodies, "Some bodies were mangled; one I walked past was completely decapitated, and the head was gone. Not a pretty sight. It was impossible not to notice how skinny these corpses were - they were obviously not very well taken care of by their regime, and you realize that they were also just fighting this war against us, as we were fighting it against them because of mainly the convictions of our different countries. Looking inside the blown up tanks - there was no real evidence of human remains. We could only depict some bone fragments in the burnt out black hulls of the tanks." 59

FAPLA's enormous defeat meant that, as a SADF report drily put it, " 47 Brigade has been driven from the southern bank of the Lomba and wil not again be able to act as a brigade". ${ }^{60}$ But it was not simply a case of the brigade being obliterated. It was the end of FAPLA's Operación Saludando à Octubre, the grand offensive to occupy Mavinga, push on to Jamba, and knock UNITA for once and for all out of the war.

Major Walter Dorning, the SADF's official chronicler of Operation Moduler's first phase, correctly judged, "Seen from a somewhat broader perspective, the destruction of 47 Brigade represented the final nail in the enemy's coffin, at least in the sense of the enemy's designs on Mavinga. With one of its four offensive brigades totally destroyed and two of the remaining three badly mauled, the enemy was left with no option but to begin withdrawing in the direction of Cuito Cuanavale." Indeed, on 5 October a FAPLA radio message was intercepted, ordering 15, 21 and 59 Brigade to start withdrawing northwards. ${ }^{61}$

Willem Steenkamp and Helmoed-Römer Heitman's conclusion is also apt, "Up to 3 October the Angolans had been advancing towards Mavinga, but after the Lomba action they were retreating and never regained the initiative." ${ }^{\prime 2}$

57 SANDF Documentation Centre. JF Huyser Collection 25/106, Interview with Commandant Smith, paragraph 38, 8 December 1987.

De Vries, p. 635.

59 Interview with Conrad Farrell, 12 April 2015.

60 SANDF Documentation Centre. JF Huyser Collection 15/51, Situation report, 4 October 1987.

61 SANDF Documentation Centre. JF Huyser Collection 40, Major Walter Dorning, pp. 76-77.

62 Steenkamp and Heitman, p. 778. 


\section{ANALYSIS}

In international military history, there are several examples of total tactical victory. These could, for instance, be cases where one side yielded without a battle, as happened in 1805 when the Austrian General Karl Freiherr Mack von Leiberich was trapped in near Ulm in Bavaria with his army of over 70000 men and surrendered to Napoleon with minimal resistance. ${ }^{63}$ This was just about the culmination of tactical art. Referring to - inter alia - Napoleon's Ulm campaign, Basil Liddell Hart writes, "The perfection of strategy [in modern jargon, operational art] would be, therefore, to produce a decision without any serious fighting." 64

However, this, of course, very rarely happens. Therefore, the next best thing is to extract the largest profit for the smallest price possible. That happened, for instance, in the northern spring of 216 B.C., when the Carthaginian General Hannibal surrounded a Roman army and all but wiped it out. Perhaps as much as 50000 Roman soldiers were killed in, what the classical scholar Victor Hanson described as, "a battlefield Armageddon unrivalled until the twentieth century". Cannae, in fact, became the template for many later military commanders. These included the German General Alfred von Schlieffen, author of the famous Schlieffen Plan with which the Germans went to war in 1914, United States General Dwight Eisenhower, commander of the Allied Forces in the West in World War II, and General Norman Schwarzkopf, commander of the forces confronting Iraq dictator Saddam Hussein in the 1991 Gulf War. ${ }^{65}$

Yet, another prime example would be the five months lasting Battle of Stalingrad. There the German Sixth Army was skilfully drawn into the urban wasteland of Stalingrad where the superior German mobility and armament was nullified. Then, at exactly the right moment, the Soviets, under the leadership of Field Marshal Georgy Zhukov, launched a counteroffensive against the much weaker allies of the Germans, the Italians and Rumanians, north and south of the city. Having broken through with ease, the jaws slammed shut west of Stalingrad and left the Sixth Army surrounded. After several weeks, during which the trapped Germans received far too few supplies, the tattered remnants were forced to surrender. According to military historian Antony Beevor's calculation, in excess of 100000 members of the Sixth Army died between 22 November, when the Germans were surrounded, and the final surrender on 2 February. ${ }^{66}$

63 Cf. David Chandler, The campaigns of Napoleon (London: Weidenfeld \& Nicolson, 1967), pp. 390-402.

64 Basil Liddell Hart, Strategy (New York: Frederick Praeger, 1954), p. 338.

65 Gregory Daly, Cannae. The experience of battle in the Second Punic War (London: Routledge, 2002), pp. ix-x. Cf. also, Martin van Crefeld, The art of war. War and military thought (London: Cassell, 2000), pp. 139-140.

Antony Beevor, Stalingrad (London: Penguin, 1999), pp. 439-440. 
Obviously, compared to Cannae and Stalingrad, the Battle of the Lomba was a small affair. Compared to the approximately 330000 German troops in the Sixth Army (of whom 290000 were trapped in the city), the Soviets deployed five armies with 18 infantry divisions, eight tank brigades, two motorised brigades, six cavalry divisions and an anti-tank brigade. ${ }^{67}$ At the Lomba, FAPLA suffered an estimated 600 dead and an unknown number wounded, while the South Africans lost one dead and four seriously wounded.

But, leaving the scale of the battles aside, the Lomba produced a tactical victory no less total than Cannae or Stalingrad. (Please note that this comparison has nothing to do with the influence of these battles on world history. Obviously, especially Stalingrad influenced world history decisively, while Lomba was merely of regional importance. The comparison is made purely regarding the tactical totality of the Lomba victory, nothing more.)

Take into account that the South Africans were heavily outnumbered in terms of manpower on the battlefield, as well as outgunned in terms of firepower. When the shooting started, both forces had probably approximately 1000 men on the battlefield. But this is misleading, as the real fighting at close quarters was done mainly by the less than 100 men in Charlie Squadron's three troops and Bravo Company's antitank platoon. In addition, 47 Brigade had in excess of $22 \mathrm{~T}-54 / 55$ tanks and a similar number of other armoured vehicles. On the other side, the South Africans had a total of 20 Ratel-90 armoured cars. Of these, 12 started the battle, while another eight joined in the fight towards the end.

Compared to the T-54/55 tanks, the Ratels were hopelessly outclassed. They were armed with an unstabilised, low-velocity $90 \mathrm{~mm}$ gun and protected by thin armour, designed to keep out small-arms fire only. The FAPLA tanks had thick armour and stabilised $100 \mathrm{~mm}$ guns. The Ratels' superior mobility was nullified by the somewhat difficult terrain and, especially, the slow pace of the SADF's advance.

The South Africans did have superior artillery, which played an important role at decisive stages of the battle. But even when taking that into account, looking at the numbers only, it seems astounding that they could win. Moreover, they did not simply win; they completely knocked the stuffing out of 47 Brigade. However one wants to look at it, this was one of the most complete tactical victories in military history. 


\section{LESSONS}

What can we learn from the Battle of the Lomba? Let us take the lessons one by one.

Firstly, training and discipline: It is a military adage that the sweat expended in training is saved in blood on the battlefield. This was very clear at the Lomba. The SADF participants were superbly trained by excellent instructors, and their battle instincts were then honed to perfection in continuous excercises while serving with 61 Mech before the start of Operation Moduler. On 3 October, they knew exactly what to do and how to do it, thanks to the mostly strict, but fair leadership of their officers. Their battlefield discipline was superb.

Proper training and discipline leads to the necessary skills which have to be created on all levels of the military hierarchy. Those skills lead to three things: They create trust in the command channel; they integrate the different weapons to the extent that the team (61 Mech) is more than the sum total of the separate sub-units; and they build cohesion and morale. It is the skills, integration and cohesion of a force which makes it possible for a technologically inferior group to be victorious over a group having much better technology at its disposal. ${ }^{68}$

On the Angolan side, the soldiers were often pressed into service. They were poorly trained, badly treated by their officers, and did not properly know what they were fighting for. Having been surprised, they panicked, then rallied, and after some hours of hard fighting panicked once again towards the end of the day. Their lack of training and discipline was directly responsible for many of the casualties. One Soviet advisor with FAPLA, Colonel Vyacheslav Mitaev, observed, "The Angolans hear gunfire and run. They aren't really brave soldiers. The Angolans were terrified of the South Africans. When we were in the $16^{\text {th }}$, [the] $21^{\text {st }}$ and $47^{\text {th }}$ brigades went on a three-month offensive from Cuito Cuanavale towards Jamba, many Angolans just ran away as soon as the South Africans advanced." 69

Lesson number one: Do not skimp on training and the concomitant discipline. The troops may, understandably, hate it. But on the battlefield it is indispensable.

In the second place: Often battles may be won even before the first shot is fired. Sir Basil Liddell Hart, one of the fathers of modern mechanised warfare, wrote about operational art (which he called strategy, as was the custom at the time), "Its purpose is to diminish the possibility of resistance, and it seeks to fulfil this purpose by exploiting the elements of movement and surprise (his emphasis)." Somewhat further he elaborated, writing about a military leader's task, "Hence his true aim is not so much to seek battle as to seek a strategic

68 The author acknowledges Professor Lieutenant-Colonel Abel Esterhuyse of the Military Academy at Saldanha for this valuable insight.

69 Vyacheslav Aleksandrovich Mitaev, "The tide turns". In: Shubin and Tokarev (eds), p. 27. 
[operational] situation so advantageous that if it does not of itself produce the decision, its continuation by a battle is sure to achieve this. In other words, dislocation is the aim of strategy [operational art]; its sequel may either be the enemy's dissolution or his easier disruption in battle" (his emphasis). ${ }^{70}$

Sun Tzu formulated it even stronger, "Therefore those who win every battle are not really skilful - those who render others' armies helpless without fighting are the best of all", and, "Therefore a victorious army first wins and then seeks battle". ${ }^{71}$

Deon Ferreira's management of the pre-battle moves was superb. Firstly, he twice tried to dislodge 47 Brigade from its jungle fortress south of the Lomba. But when he saw that its position was all but unassailable, he wisely abandoned further attempts. This decision was also influenced by the fact that the Brigade was isolated from its brother formations north of the river and that it was basically a dead duck. He ordered a concerted artillery and aerial bombardment in order to grind 47 Brigade down steadily and at the same time to exhaust its warfighting supplies. He knew the Brigade could not remain there. Sooner or later it would be forced to move. Thanks to the superb SADF radio interception service, he had a fairly good knowledge of the Angolan commanders' thinking. As soon as they started moving, they would come to terrain much more conducive to the SADF's mobile tactics.

So it happened. 47 Brigade, already weakened before it left its jungle hide, was vanquished before the first shot was fired on the morning of that fateful day, 3 October 1987. To combine Liddell Hart and Sun Tzu, Ferreira rendered 47 Brigade helpless before any fighting; thereafter victory became sure by the continuation of military action.

Lesson number two: Manage your battle beforehand very carefully, almost like a chess game. Know what your enemy is doing and planning. Know what the enemy's vulnerabilities are. Beat him before a shot is fired.

Thirdly: Having been rebuffed twice by 47 Brigade, Deon Ferreira let them stew. But when they came out into the open, he assaulted them in their vulnerable right flank. He achieved complete surprise. Ferreira enabled Bok Smit to keep the FAPLA defenders on their back foot throughout the battle.

Lesson number three: When you are in a position to take and retain the initiative, avoid the enemy's strong points and exploit his vulnerabilities, while avoiding your own weaknesses and emphasising your strengths. Attack the enemy where he is weak and does not expect it. Do not fight him on ground of his choosing, but where the terrain favours you. Surprise the enemy whenever possible.

In the fourth place, we may look at command and control. The Battle of the Lomba is an excellent example of cooperation between the operational

70 Hart, pp. 337, 339. Liddell Hart's emphasis.

71 Sun Tzu, pp. 67, 91. 
commander (Deon Ferreira) and the tactical commander on the spot (Bok Smit). The battle plan was devised by both, plus their staff officers together. The last contact between Ferreira and Smit was at 02:00 on the morning of 3 October. Although Smit kept Ferreira informed by radio throughout the day, there is no indication that Ferreira intervened at any stage. Even the decision to break off the fighting and pull back twice in order to resupply the Ratels was taken by Smit alone. ${ }^{72}$ This was in accordance to the SADF's battlefield culture, according to which tactical decisions are taken at a lower, rather than higher, level. Typically, operational headquarters would decide where, when and against whom to fight, and what the basic outline of the battle should be. But someone like Ferreira knew that, once battle was joined, he had to hand the reigns to Smit and let him do his thing.

Robert Leonhard identifies two kinds of command and control. The first is known as "directive control", "The idea is that in order to exploit opportunities and the initiative of subordinates, the commander should confine his operations order to explaining the mission and his intent regarding the enemy. Including only such details as are absolutely necessary to coordinate the actions of subordinates, he should allow his subordinates the freedom to figure out how to accomplish the task, rather than oversupervising each step of the operation." ${ }^{33}$

The second is "detailed control", in which, he writes, "the subordinate leaders are given very little room to decide their own courses of action. They are expected, not so much to innovate, but rather to carry out the specific orders of the commander relentlessly." ${ }^{4}$

Contrary to general belief, the Germans were traditionally not at all rigid about their command and control. They practised directive control (which they called Auftragstaktik) very successfully. This was also taken over by the SADF. On the other hand, detailed control (German: Befeh/staktik) was characteristic of the Soviet army. As the Soviet military were the advising and driving force behind FAPLA, this culture also permeated the Angolan Army. Indeed, when looking at the radio messages intercepted by the SADF before and during the Battle of the Lomba, one gets the distinct impression that the Angolan $\mathrm{HQ}$ at Cuito Cuanavale breathed down the 47 Brigade leadership's necks all the time. ${ }^{75}$

Lesson number four: Establish a bond of trust between the commanders on different levels. Once the higher $\mathrm{HQ}$ has set out the basic course of the battle, leave the tactical commanders on the ground to do their thing, as long as these

72 Scholtz, Ratels on the Lomba, ch. 7-9.

73 Robert Leonhard, The art of maneuver. Maneuver-warfare theory and air land battle (Novato: Presidio, 1991), p. 50.

74 Ibid., p. 53.

75 Cf. SANDF Documentation Centre. JF Huyser Collection 27/122, various intercepted messages. 
stay within the agreed parameters. Let them make their decisions independently; as they are on the spot and best suited to do that.

Sadly, later in the campaign, the SADF generals in Pretoria - officers without operational experience - deviated from this cardinal principle. They intervened in a way never seen in the SADF since the Second World War. And on tactical, as well as operational level, the SADF paid the price. ${ }^{76}$

Fifth: Things could potentially have gone horribly wrong for the South Africans when they stumbled upon the full 47 Brigade near the TMM bridge, instead of just the advance party they expected. It is not known whether the SADF commanders contemplated abandonment of the attack, but the thought must at least have crossed their minds. It seems logical to assume, however, that they were satisfied that all other conditions for victory were favourable. Therefore, they kept their nerve and pressed on.

Lesson number five: If you have complete surprise, if you attack the enemy in a vulnerable position, if you have complete initiative, chances are that fortune will favour the brave. This has been illustrated all through history.

Six: When the South African Government made the political decision to intervene in the Angolan Civil War and save UNITA from being knocked out, the decision how many forces to employ was, quite correctly, left to the SADF leadership. However, the first phase of Operation Moduler was undertaken with a force that was absolutely inadequate for the job. 20 SA Brigade had the equivalent of two battalion-sized units (though mixed up in three combat groups for maximum flexibility) and an artillery regiment - a force of 2609 men. Against them was arrayed four FAPLA brigades with approximately 6000 men. More importantly, the South Africans had a total of 32 Ratels suited to destroy tanks (12 Ratel-90s in Charlie Squadron, 61 Mech; eight Ratel-90s in the antitank platoon, $61 \mathrm{Mech}$; eight Ratel-90s in the antitank squadron, 32 Battalion; and four experimental missile-equipped Ratel-ZT3s in the antitank squadron, 32 Battalion). On the other hand, the enemy had about $80 \mathrm{~T}-54 / 55$ tanks (obsolescent, to be sure, but still more than a match for the Ratel). ${ }^{77}$

One has to ask the question, even though it has to be couched in unacademic words: What kind of military madness was it to throw such an inadequate force against such an overwhelming enemy juggernaut - and to expect them to win? And yet: They did not simply win; they completely crushed the enemy. One wonders how this would have turned out if commanders of a lesser calibre than Deon Ferreira and Bok Smit were in charge of the South Africans on 3 October 1987.

Lesson number six: Having established what it is you want to achieve with a campaign or a battle, give your commanders on the spot the tools they need. While one has to salute the South Africans for their magnificent victory, one also

76 Scholtz, The SADF in the Border War, ch. 13-15.

77 Scholtz, Ratels on the Lomba, ch. 4. 
has to see how near to a catastrophe they had come. Losing the battle would likely have changed the late 20th century history of southern Africa to a large extent. That this did not happen, was no thanks to the SADF generals. 